\title{
PENGARUH KOMPENSASI FINANSIAL, BUDAYA ORGANISASI DAN KEPEMIMPINAN TERHADAP TURNOVER INTENTION KARYAWAN KOPERASI ASADANA SEMESTA DENPASAR
}

\author{
Ida Bagus Gede Wirabawa Dhananjaya ${ }^{1}$ \\ I Gusti Ayu Manuati Dewi ${ }^{2}$ \\ ${ }^{1,2}$ Fakultas Ekonomi dan Bisnis Universitas Udayana (Unud), Bali, Indonesia \\ e-mail: wirabawadhananjaya@gmail.com
}

\begin{abstract}
ABSTRAK
Turnover intention merupakan intensi atau kecenderungan seseorang keluar dari organisasi dengan suatu alasan tertentu. Turnover intention akan menghambat kegiatan operasional sebuah perusahaan, maka penelitian ini bertujuan untuk mengetahui pengaruh kompensasi finansial, budaya organisasi dan kepemimpinan terhadap turnover intention di Koperasi Asadana Semesta Denpasar. Landasan teori yang digunakan dalam penelitian ini adalah Theory Of Reasoned Action yang menjelaskan tentang tindakan beralasan yang dipengaruhi niat dan niat dipengaruhi oleh kepercayaan. Sampel dalam penelitian ini adalah seluruh karyawan Koperasi Asadana Semesta Denpasar yang berjumlah 47 orang tidak termasuk pimpinan. Metode penentuan sampel dalam penelitian ini menggunakan saturate sampling yang artinya seluruh populasi digunakan sebagai sampel. Pengumpulan data dilakukan dengan penyebaran kuesioner menggunakan skala likert 5 poin untuk mengukur 20 butir pernyataan. Teknik analisis yang digunakan adalah analisis regresi linier berganda. Hasil analisis menunjukan bahwa kompensasi finansial, budaya organisasi dan kepemimpinan berpengaruh negatif terhadap turnover intention. Perusahaan diharapkan lebih memperhatikan pemberian kompensasi yang adil, menerapkan budaya organisasi secara konsisten dan meningkatkan kualitas pemimpin untuk menekan tingginya turnover karyawan dalam perusahaan.
\end{abstract}

Kata Kunci: kompensasi finansial, budaya organisasi, kepemimpinan dan turnover intention

\begin{abstract}
Turnover intention is the tendency of employees leaving the organization for some reason. Turnover intention will hinders the company's operational activities, so this research to know about the influence of financial compensation, organizational culture and leadership against turnover intention at Asadana Semesta Cooperative in Denpasar. The theoretical basis used is the theory of reasoned action that explains the reasoned actions that are influenced by the intention, while the intention is influenced by the belief. The sample in this research is all employee's at Asadana Semesta Cooperative, They are 47 employee's but not include the leader. Sample research methods that used in this research is saturated sampling which is the whole population used as a sample. Those are using likert scale 5 points to measure 20 points of statement. The analytical technique that used is multiple linier regression analysis. Analysis result show that compensation, organizational culture and leadership have a negative effect for turnover intention. The company expected to sive more attention for siving the fair compensation and improving the quality of a leader to prevent the high number of turnover employee's within the company.
\end{abstract}

Keywords: financial compensation, organizational culture, leadership and turnover intention 


\section{PENDAHULUAN}

Sumber daya manusia (SDM) merupakan roda penggerak dalam menjalankan kegiatan operasional perusahaan. Manusia adalah sumber daya yang sangat penting, oleh karena itu dibutuhkan sumber daya yang berkualitas untuk menunjang operasional perusahaan. Kegiatan operasional perusahaan dapat berjalan dengan lancar apabila gangguan yang berasal dari baik lingkungan internal maupun eksternal perusahaan mampu diminimalisir. Untuk mengelola SDM secara optimal, setiap pemimpin atau manajer serta bagian yang menangani SDM harus mengerti masalah manajemen SDM dengan baik (Widodo, 2015:2). Karyawan sebagai modal utama perusahaan, perlu dikelola agar tetap menjadi produktif, namun pengelolaannya bukanlah hal yang mudah, karena mereka mempunyai pikiran, status, serta latar belakang yang berbeda (Mulyati, 2003).

Pengelolaan SDM sangat penting dilakukan demi menjamin kelancaran aktifitas perusahaan. Untuk itu, diperlukan perencanaan, pengorganisasian, pengarahan dan pengawasan. Tanpa unsur-unsur tersebut kegiatan yang dilakukan menjadi tidak jelas, sehingga muncul masalah internal perusahaan. Masalah internal perusahaan yang berlangsung terus menerus mengakibatkan pemikiran negatif dan rasa cemas bagi karyawan.

Timbulnya rasa cemas memungkinkan karyawan berpikir tentang keberlangsungan kinerja dalam organisasi. Menurut Cinar et al. (2014) karyawan yang merasa cemas dan tidak nyaman dengan sukarela akan berpikir untuk mencari lingkungan baru yang lebih baik dari pada organisasi yang sekarang. Apabila intensitas karyawan untuk keluar dari organisasi (turnover intention) 
Ida Bagus Gede Wirabawa Dhananjaya, Pengaruh Kompensasi Finansial, Budaya...

tinggi, maka akan merugikan perusahaan karena perusahaan akan mengeluarkan biaya untuk mengisi kekososongan posisi yang ditinggalkan seperti perekrutan karyawan baru dan pelatihan kerja (Fah et al., 2010).

Dengan adanya indikasi ketidaknyamanan karyawan, akan mengakibatkan intensitas keinginan untuk keluar dari perusahaan semakin bertambah dan berujung pada turnover yang tinggi di suatu perusahaan. Dengan kata lain turnover intention merupakan keinginan untuk keluar dari perusahaan, saat keinginan keluar dari perusahaan terealisasi maka disebut dengan turnover. Turnover telah menjadi agenda riset yang penting untuk diteliti bagi pengembangan sumber daya manusia (Baek-Kyoo dan Sunyoung, 2009). Permasalahan turnover yang tinggi terjadi pula di Koperasi Asadana Semesta Denpasar. Tabel 1 menunjukan data keadaan keluar masuknya karyawan Koperasi Asadana Semesta Denpasar pada tahun 2014 hingga 2017.

Tabel 1.

Data Keadaan Keluar Masuk Karyawan Tahun 2014 - 2017

\begin{tabular}{cccccc}
\hline Tahun & $\begin{array}{c}\text { Masuk } \\
(1)\end{array}$ & $\begin{array}{c}\text { Keluar } \\
(2)\end{array}$ & $\begin{array}{c}\text { Jumlah Awal } \\
(3)\end{array}$ & $\begin{array}{c}\text { Jumlah Akhir } \\
(4)\end{array}$ & Turnover \\
\hline 2014 & 10 & 8 & 51 & 53 & $17,30 \%$ \\
2015 & 9 & 11 & 53 & 51 & $19,23 \%$ \\
2016 & 10 & 17 & 51 & 44 & $28,42 \%$ \\
2017 & 14 & 11 & 44 & 47 & $27,47 \%$ \\
\hline
\end{tabular}

Sumber :Human Resources Departement Koperasi Asadana Semesta, 2017

Panggabean (2004:20), menyatakan bahwa untuk mengetahui turnover di suatu perusahaan dapat dihitung dengan rumus sebagai berikut :

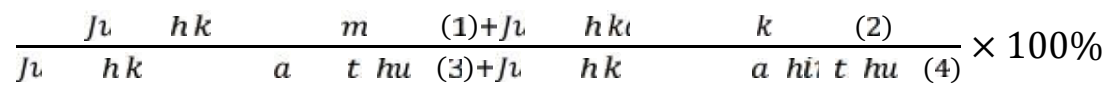


Koperasi Asadana Semesta memiliki turnover karyawan yang cukup tinggi. Dari hasil perhitungan tingkat turnover pada tahun 2014 sampai 2017 di Koperasi Asadana Semesta Denpasar berturut-turut sebesar 17,30\%, 19,23\%, 28,42\% dan 27,47\% yang lebih besar dari 10\%. Mengacu pada pendapat Gillies (1989) tingkat perputaran karyawan dikatakan normal apabila berada dalam kisaran 5-10\% per tahun. Jika tingkat perputaran karyawan lebih dari $10 \%$ per tahun maka turnover karyawan dikatakan tinggi. Turnover karyawan Koperasi Asadana Semesta Denpasar per tahun lebih dari 10\%, maka turnover karyawan Koperasi Asadana Semesta Denpasar dikatakan tinggi, untuk itu perlu diketahui faktor penyebab turnover intention karyawan di Koperasi Asadana Semesta Denpasar.

Kompensasi finansial merupakan faktor penting yang mempengaruhi bagaimana dan mengapa karyawan bekerja pada perusahaan dan bukan perusahaan lainnya (Orwa, 2012). Mathis dan Jackson (dalam Putrianti, 2014) menyatakan bahwa kompensasi merupakan hak karyawan dan kewajiban bagi perusahaan untuk membayarnya. Menurut hasil penelitian Devi dan Sudibia (2015) kompensasi berpengaruh negatif signifikan terhadap turnover intention, Shun (2011) sependapat bahwa semakin tinggi kompensasi maka semakin kecil keinginan karyawan meninggalkan organisasi karena merasa dihargai dan kebutuhannya terpenuhi.

Selain kompensasi finansial, budaya organisasi dapat mempengaruhi turnover intention dikarenakan karyawan akan merasa terikat dengan nilai-nilai organisasi yang ada dan karyawan akan merasa senang mengerjakan tugas dan kewajiban sebaik mungkin, sehingga mengurangi turnover intention (Malik 
Ida Bagus Gede Wirabawa Dhananjaya, Pengaruh Kompensasi Finansial, Budaya...

2014). Lewis (2002) menyatakan bahwa budaya organisasi adalah keberadaan nilai, kepercayaan dan asumsi yang memberikan arah bagi individu dalam organisasi. Flynn dan Chatman (2001) menyatakan bahwa budaya organisasi berperan sebagai pengaruh sikap serta prilaku melalui nilai-nilai organisasi.

Faktor ketiga yang dapat berkontribusi terhadap keinginan karyawan untuk tetap tinggal dalam organisasi adalah kepemimpinan. Choi dan Lee (2011) menyatakan bahwa kepemimpinan berpengaruh negatif terhadap turnover intention. Hasil studi Astiko (2012) menunjukan bahwa kepemimpinan berpengaruh negatif terhadap turnover intention karena kepemimpinan yang baik menyebabkan karyawan merasa nyaman, sehingga karyawan akan mempertimbangkan kembali apabila ingin meninggalkan pemimpinnya.

Sejumlah penelitian telah dilakukan untuk mengetahui pengaruh kompensasi finansial terhadap turnover intention. Jandu (2015) menyatakan bahwa adanya pengaruh negatif signifikan kompensasi finansial terhadap turnover intention pada PT Zenith Allmart Precisindo Sidoarjo. Sistem kompensasi finansial yang baik mampu menekan intensitas keinginan karyawan untuk keluar dari perusahaan. Putrianti (2014) berpendapat sama, bahwa kompensasi finansial berpengaruh signifikan terhadap turnover intention. Kompensasi finansial merupakan alasan utama individu bekerja pada perusahaan, Apabila kompensasi finansial memenuhi kebutuhan hidup, intensitas keinginan karyawan keluar dari perusahaan semakin berkurang. Sukron (2011) berpendapat adanya kompensasi finansial selain gaji pokok seperti insensif dan tunjangan mengurangi intensitas 
keinginan karyawan keluar dari perusahaan PT. Garudafood Jawa Tengah. Berdasarkan hal tersebut maka dapat dirumuskan hipotesis sebagai berikut:

$\mathrm{H}_{1}$ : Kompensasi finansial berpengaruh negatif terhadap turnover intention.

Penelitian Malik (2014) dan Shim (2010) menunjukan hasil bahwa budaya organisasi berpengaruh negatif terhadap turnover intention. Pendapat tersebut didukung oleh penelitian dari Setyanto (2013) yang menyatakan budaya organisasi berpengaruh negatif terhadap turnover intention di perusahaan Teladan Prima Group. Budaya organisasi merupakan nilai yang tertanam dalam setiap individu dalam organisasi. Dengan nilai budaya yang dianut organisasi akan memperkuat ikatan individu dengan individu lain untuk bekerjasama. Widayati dan Yunia (2016) berpendapat apabila budaya organisasi kuat maka intensitas keinginan keluar karyawan akan menurun. Berdasarkan hal tersebut, maka dapat dirumuskan hipotesis sebagai berikut :

$\mathrm{H}_{2}$ : Budaya organisasi berpengaruh negatif terhadap turnover intention.

Kepemimpinan adalah kemampuan atau seni yang dimiliki seorang pemimpin untuk mempengaruhi individu lainnya guna mencapai tujuan yang ditetapkan. Krisyanto (2005) menyatakan bahwa kepemimpinan berpengaruh negatif signifikan keinginan karyawan untuk meninggalkan organisasi. Pendapat tersebut didukung penelitian Astiko (2012) bahwa kepemimpinan berpengaruh negatif terhadap turnover intention melalui kepuasan kerja. Artinya pimpinan yang mampu mengarahkan karyawan sesuai tata tertib dan tujuan organisasi berdampak terhadap kepuasan karyawan sehingga menurunkan niat karyawan 
Ida Bagus Gede Wirabawa Dhananjaya, Pengaruh Kompensasi Finansial, Budaya...

untuk meninggalkan RS Panti Wilasa Citarum Semarang. Dalam penelitian Sukron (2011) digambarkan bahwa kepemimpinan berpengaruh negatif signifikan terhadap turnover intention. Pemimpin menginspirasi bawahan dengan memberikan solusi yang tepat dalam pemecahan masalah dan seorang bawahan akan merasa nyaman yang menyebabkan keinginan bawahan pindah dari perusahaan menurun. Berdasarkan hal tersebut, maka dapat dirumuskan hipotesis sebagai berikut.

$\mathrm{H}_{3}$ : Kepemimpinan berpengaruh negatif terhadap turnover intention.

Untuk memperjelas keterkaitan antara kompensasi finansial, budaya organisasi, kepemimpinan dan turnover intention maka perlu dibuat model konseptual yang menggambarkan secara ringkas hubungan antara masing-masing variabel seperti terlihat pada Gambar 1 .

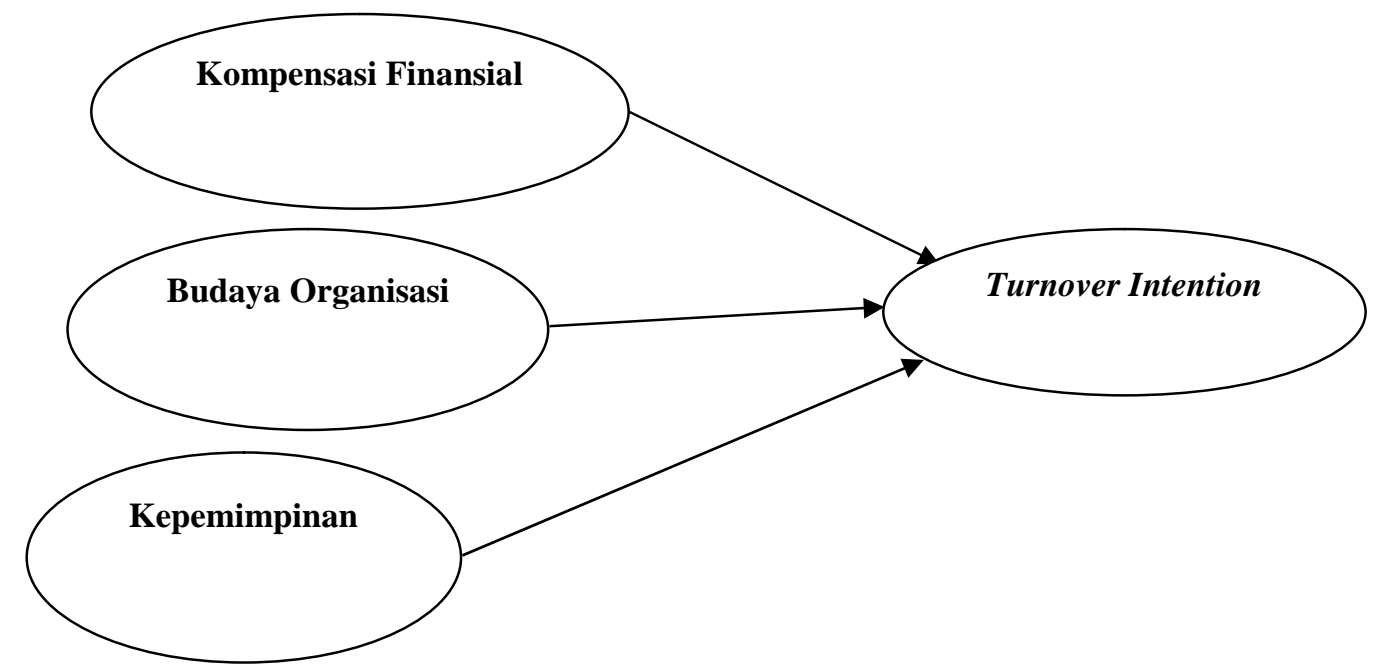

Gambar 1. Model Konseptual Penelitian 


\section{METODE PENELITIAN}

Pendekatan yang digunakan dalam penelitian ini adalah pendekatan asosiatif kausalitas. Pendekatan ini adalah suatu pendekatan yang menunjukan hubungan antar dua variabel atau lebih. Pendekatan ini digunakan karena bertujuan untuk menguji hubungan sebab-akibat dua variabel atau lebih. Penelitian ini dilakukan di Koperasi Asadana Semesta yang beralamat di Jl.Gn. Soputan No.49 Denpasar. Lokasi ini dipilih karena terdapat masalah mengenai turnover intention. Objek penelitian ini adalah kompensasi finansial, budaya organisasi, kepemimpinan, dan turnover intention. Pada Tabel 2 dapat dilihat identifikasi variabel, definisi operasional dan indikator masing-masing variabel penelitian.

Tabel 2.

Identifikasi, Definisi Operasional, dan Indikator Variabel Penelitian

\begin{tabular}{|c|c|c|}
\hline Variabel & Definisi Operasional & Indikator Variabel \\
\hline Kompensasi & Balas jasa yang diterima oleh & 1) Kesesuaian gaji dengan kebutuhan \\
\hline \multirow{2}{*}{ Finansial $\left(\mathrm{X}_{1}\right)$} & karyawan dari perusahaan & hidup. \\
\hline & sebagai akibat dari jasa atau & 2) Kesesuaian insentif dengan harapan. \\
\hline Winoto (2015) & $\begin{array}{l}\text { tenaga yang telah diberikan } \\
\text { karyawan pada perusahaan. }\end{array}$ & $\begin{array}{l}\text { 3) Kesesuaian tunjangan dengan } \\
\text { harapan. }\end{array}$ \\
\hline Budaya & Nilai bersama yang diyakini & 1) Integritas. \\
\hline \multirow[t]{2}{*}{ Organisasi $\left(\mathrm{X}_{2}\right)$} & oleh anggota organisasi. & 2) Optimisme. \\
\hline & & 3) Profesionalisme. \\
\hline Fuad (2004) & & 4) Kepedulian. \\
\hline \multirow{3}{*}{$\begin{array}{l}\text { Kepemimpinan } \\
\left(\mathrm{X}_{3}\right)\end{array}$} & Kemampuan atau seni yang & 1) Kepandaian membaca situasi \\
\hline & dimiliki individu untuk & 2) Peka terhadap masukan. \\
\hline & mempengaruhi individu lainnya & 3) Menciptakan suasana lingkungan \\
\hline \multirow[t]{4}{*}{ Sukron (2011) } & untuk bergerak sesuai & yang baik. \\
\hline & $\begin{array}{l}\text { keinginan dan tujuan yang } \\
\text { ingin dicapai }\end{array}$ & $\begin{array}{l}\text { 4) Kesediaan melimpahkan sebagian } \\
\text { wewenang kepada karyawan. }\end{array}$ \\
\hline & & 5) Kemampuan memberikan tugas. \\
\hline & & 6) Menciptakan suasana saling percaya. \\
\hline \multirow{4}{*}{$\begin{array}{l}\text { Turnover } \\
\text { Intention (Y) } \\
\text { Negara (2017) }\end{array}$} & $\begin{array}{l}\text { Keinginan atau niat untuk } \\
\text { meninggalkan organisasi }\end{array}$ & $\begin{array}{l}\text { 1) Kecenderungan individu berpikir } \\
\text { meninggalkan organisasi saat ini. }\end{array}$ \\
\hline & dengan hasrat yang disengaja & 2) Kemungkinan individu mencari \\
\hline & oleh karyawan & pekerjaan baru di tahun depan. \\
\hline & & $\begin{array}{l}\text { 3) Kemungkinan individu } \\
\text { meninggalkan organisasi dalam } \\
\text { beberapa bulan kedepan. }\end{array}$ \\
\hline
\end{tabular}


Ida Bagus Gede Wirabawa Dhananjaya, Pengaruh Kompensasi Finansial, Budaya...

Populasi penelitian ini adalah seluruh karyawan Koperasi Asadana Semesta Cabang Denpasar yang berjumlah 47 orang tidak termasuk pimpinan yaitu Kepala Cabang, Kepala Bagian Marketing, Kepala Bagian Operasional, dan Kepala Bagian Penagihan. Teknik sampling yang digunakan adalah saturated sampling yaitu mengambil populasi sebagai sampel. Responden dari penelitian ini adalah seluruh karyawan yang bekerja di Koperasi Asadana Semesta Denpasar. Distribusi responden pada penelitian ini dapat dilihat pada Tabel 3.

Tabel 3.

Distribusi Responden Koperasi Asadana Semesta Denpasar

\begin{tabular}{ccc}
\hline No & Jabatan & Jumlah (orang) \\
\hline 1 & Marketing & 9 \\
2 & Kolektor & 11 \\
3 & Surveyor & 3 \\
4 & Kasir & 2 \\
5 & Administrasi & 12 \\
6 & Accounting Officer & 5 \\
7 & Customer Service & 5 \\
\hline & Total & 47 \\
\hline
\end{tabular}

Sumber: Human Resources Departement Koperasi Asadana Semesta.

Teknik analisis data yang digunakan dalam penelitian ini adalah Regresi Linier Berganda. Model regresi linier berganda yang dimaksud, dirumuskan sebagai berikut.

$Y=\alpha+\beta_{1} X_{1}+\beta_{2} X_{2}+\beta_{3} X_{3}+\varepsilon$

Dimana :

$\mathrm{Y} \quad=$ Turnover Intention

$\mathrm{X}_{1} \quad=$ Kompensasi

$\mathrm{X}_{2} \quad$ = Budaya organisasi

$\mathrm{X}_{3} \quad=$ Kepemimpinan

$\alpha \quad=$ Konstanta

$\beta_{1} \quad=$ Koefisien Variabel $\mathrm{X}_{1}$

$\beta_{2} \quad=$ Koefisien Variabel $X_{2}$

$\beta_{3} \quad=$ Koefisien Variabel $X_{3}$

$\varepsilon \quad=$ Eror of term (Variabel yang tidak terungkap) 
Pengaruh variabel bebas terhadap variabel terikat diuji dengan tingkat kepercayaan $95 \%$ atau $\alpha=5 \%$.

\section{HASIL DAN PEMBAHASAN}

\section{Karakteristik Responden}

Uraian tentang karakteristik responden dalam penelitian ini dikelompokan ke dalam jenis kelamin, usia, dan tingkat pendidikan. Data tentang karakteristik responden dapat dilihat pada Tabel 4.

Tabel 4.

Karakteristik Responden

\begin{tabular}{|c|c|c|c|c|}
\hline No. & Variabel & Klasifikasi & $\begin{array}{l}\text { Jumlah } \\
\text { (orang) }\end{array}$ & Persentase \\
\hline \multirow{3}{*}{1} & \multirow{2}{*}{ Jenis Kelamin } & Laki - laki & 25 & 53,20 \\
\hline & & Perempuan & 22 & 46,80 \\
\hline & \multicolumn{2}{|c|}{ Jumlah } & 47 & 100 \\
\hline \multirow{4}{*}{2} & \multirow{3}{*}{ Usia } & $20-30$ & 25 & 53,20 \\
\hline & & $31-40$ & 20 & 42,55 \\
\hline & & $41-50$ & 2 & 4,25 \\
\hline & \multicolumn{2}{|c|}{ Jumlah } & 47 & 100 \\
\hline \multirow{5}{*}{3} & \multirow{4}{*}{ Tingkat Pendidikan } & SMA & 17 & 36,17 \\
\hline & & SMK & 6 & 12,76 \\
\hline & & Diploma & 4 & 8,52 \\
\hline & \multirow{2}{*}{\multicolumn{2}{|c|}{ Jumlah }} & 20 & 42,55 \\
\hline & & & 47 & 100 \\
\hline
\end{tabular}

Sumber: Data primer diolah, 2017.

Pada Tabel 4 tampak bahwa responden yang berjenis kelamin laki-laki berjumlah 25 orang $(53,20 \%)$. Sisanya yakni 22 orang $(46,80 \%)$ berjenis kelamin perempuan. Jumlah karyawan lak-laki lebih banyak dari perempuan dikarenakan kebutuhan akan tenaga kerja lapangan yang memerlukan fisik prima untuk melayani penjemputan pembayaran sebagai pelayanan utama Koperasi Asadana Semesta Denpasar.

Sebagian besar responden, yakni sekitar 53,20\% berusia 20-30 tahun. Sisanya berusia $31-40$ tahun sebanyak $42,55 \%$ dan $4,25 \%$ berusia $41-50$ tahun. 
Ida Bagus Gede Wirabawa Dhananjaya, Pengaruh Kompensasi Finansial, Budaya...

Banyaknya karyawan berusia 20-30 menunjukan bahwa Koperasi Asadana Semesta Denpasar bertujuan mengoptimalkan pelayanan kepada nasabah, menjual produk dengan cepat, semangat tinggi dan berinovasi dalam produk, sehingga menggunakan karyawan berusia relative lebih muda.

Proporsi tingkat pendidikan tertinggi dari responden penelitian adalah S1 yakni 20 orang atau sebesar 42,55\%, sedangkan yang terendah pada tingkat pendidikan Diploma yakni 4 orang atau sebesar 8,52\%. Sisanya, 17 orang $(36,17 \%)$ dengan tingkat pendidikan SMA dan 6 orang $(12,76 \%)$ dengan tingkat pendidikan SMK. Tingginya jumlah tingkat pendidikan karyawan S1 dikarenakan Koperasi Asadana Semesta Denpasar berharap karyawan mampu dikembangkan tidak hanya dengan satu bidang kemampuan saja, begitu juga dengan karyawan lain dengan tingkat pendidikan yang berbeda diharapkan mampu bersaing.

\section{Uji Validitas dan Reliabilitas Instrumen Penelitian}

Suatu instrumen dikatakan valid jika korelasi antara skor faktor dengan skor total bernilai positif dan nilainya lebih dari 0,30 . Sedangkan instrumen dikatakan reliabel apabila koefisien lebih dari 0,60. Hasil Uji Validitas dan Reliabilitas dapat dilihat pada tabel 5 dan 6.

Hasil uji validitas pada Tabel 5 menunjukkan bahwa seluruh variabel memiliki nilai koefisien korelasi dengan skor total seluruh butir pernyataan lebih besar dari 0,30. Hal ini menunjukkan bahwa butir-butir pernyataan dalam instrumen penelitian dapat dikatakan valid. 
Tabel 5.

Hasil Uji Validitas

\begin{tabular}{cccc}
\hline Variabel & Indikator & Koefisien Korelasi & Keterangan \\
\hline \multirow{4}{*}{ Kompensasi Finansial $\left(\mathrm{X}_{1}\right)$} & $\mathrm{X}_{1.1}$ & 0,835 & Valid \\
& $\mathrm{X}_{1.2}$ & 0,797 & Valid \\
& $\mathrm{X}_{1.3}$ & 0,873 & Valid \\
& $\mathrm{X}_{1.4}$ & 0,648 & Valid \\
& $\mathrm{X}_{1.5}$ & 0,742 & Valid \\
\hline \multirow{5}{*}{ Budaya Organisasi $\left(\mathrm{X}_{2}\right)$} & $\mathrm{X}_{2.1}$ & 0,681 & Valid \\
& $\mathrm{X}_{2.2}$ & 0,818 & Valid \\
& $\mathrm{X}_{2.3}$ & 0,837 & Valid \\
& $\mathrm{X}_{2.4}$ & 0,613 & Valid \\
& $\mathrm{X}_{2.5}$ & 0,761 & Valid \\
& $\mathrm{X}_{2.6}$ & 0,786 & Valid \\
\hline \multirow{5}{*}{ Kepemimpinan $\left(\mathrm{X}_{3}\right)$} & $\mathrm{X}_{3.1}$ & 0,628 & Valid \\
& $\mathrm{X}_{3.2}$ & 0,860 & Valid \\
& $\mathrm{X}_{3.3}$ & 0,633 & Valid \\
& $\mathrm{X}_{3.4}$ & 0,635 & Valid \\
& $\mathrm{X}_{3.5}$ & 0,858 & Valid \\
& $\mathrm{X}_{3.6}$ & 0,867 & Valid \\
\hline \multirow{3}{*}{ Turnover Intention $(\mathrm{Y})$} & $\mathrm{Y}_{1}$ & 0,789 & Valid \\
& $\mathrm{Y}_{2}$ & 0,917 & Valid \\
& $\mathrm{Y}_{3}$ & 0,847 & Valid \\
\hline
\end{tabular}

Sumber : Data diolah, 2018.

Tabel 6.

Hasil Uji Reliabilitas

\begin{tabular}{clcc}
\hline No. & \multicolumn{1}{c}{ Variabel } & Cronbach'sAlpha & Keterangan \\
\hline 1 & KompensasiFinansial $\left(\mathrm{X}_{1}\right)$ & 0,893 & Reliabel \\
2 & Budaya Organisasi $\left(\mathrm{X}_{2}\right)$ & 0,887 & Reliabel \\
3 & Kepemimpinan $\left(\mathrm{X}_{3}\right)$ & 0,892 & Reliabel \\
4 & Turnover Intention $(\mathrm{Y})$ & 0,906 & Reliabel \\
\hline
\end{tabular}

Sumber: Data diolah, 2018.

Hasil uji reliabilitas yang disajikan pada Tabel 6 menunjukkan bahwa seluruh variabel penelitian memiliki koefisien Cronbach's Alpha lebih dari 0,60. Hal ini dapat dikatakan bahwa semua variabel reliable, sehingga dapat digunakan untuk analisis data selanjutnya.

\section{Penilaian Responden Tentang Turnover Intention}

Penilaian responden tentang turnover intention diukur dengan 3 butir pernyataan. Data tentang pernyataan tersebut dapat dilihat pada Tabel 7. 
Ida Bagus Gede Wirabawa Dhananjaya, Pengaruh Kompensasi Finansial, Budaya...

Tabel 7.

Jawaban Responden Tentang Turnover Intention

\begin{tabular}{|c|c|c|c|c|c|c|c|c|}
\hline \multirow{2}{*}{ No } & \multirow{2}{*}{ Pernyataan } & \multicolumn{5}{|c|}{ Proporsi Jawaban Responden } & \multirow{2}{*}{$\begin{array}{l}\text { Rata- } \\
\text { Rata }\end{array}$} & \multirow{2}{*}{ Kriteria } \\
\hline & & STS & TS & $\mathrm{N}$ & $\mathrm{S}$ & SS & & \\
\hline 1 & $\begin{array}{l}\text { Saya sering berfikir untuk } \\
\text { berhenti dari pekerjaan saya } \\
\text { sekarang. }\end{array}$ & 5 & 17 & 16 & 6 & 3 & 2,68 & Sedang \\
\hline 2 & $\begin{array}{l}\text { Saya mungkin akan mencari } \\
\text { pekerjaan baru di tahun } \\
\text { depan. }\end{array}$ & 11 & 11 & 10 & 11 & 4 & 2,70 & Sedang \\
\hline 3 & $\begin{array}{l}\text { Sesegera mungkin saya akan } \\
\text { meninggalkan perusahaan ini. }\end{array}$ & 9 & 10 & 10 & 14 & 4 & 2,87 & Sedang \\
\hline \multicolumn{7}{|c|}{ Rata-rata } & 2,75 & Sedang \\
\hline
\end{tabular}

Sumber : Data diolah, 2018.

Tabel 7 menunjukan bahwa rata-rata dari 3 pernyataan responden mengenai turnover intention yaitu sebesar 2,75 yang berarti turnover intention karyawan Koperasi Asadana Semesta Denpasar tergolong dalam kriteria sedang. Indikator yang memiliki rata-rata perhitungan skor tertinggi pada pernyataan "Sesegera mungkin saya akan meninggalkan perusahaan ini" dengan nilai rata-rata 2,87. Nilai rata-rata tersebut menunjukan bahwa 14 orang karyawan memiliki keinginan untuk sesegera mungkin meninggalkan perusahaan. Sedangkan indikator dengan rata-rata terendah ditunjukan pada pernyataan "Saya sering berfikir untuk berhenti dari pekerjaan saya sekarang" dengan nilai rata-rata 2,68. Pernyataan tersebut tidak disetujui oleh 17 orang responden, namun 6 orang responden sering berfikir untuk meninggalkan perusahaan, ini berarti menunjukan bahwa beberapa karyawan ingin meninggalkan perusahaan.

\section{Penilaian Responden Tentang Kompensasi Finansial}

Penilaian responden tentang kompensasi finansial diukur dengan 5 butir pernyataan. Data tentang pernyataan tersebut dapat dilihat pada Tabel 8. 
Tabel 8.

Jawaban Responden Tentang Kompensasi Finansial

\begin{tabular}{|c|c|c|c|c|c|c|c|c|}
\hline \multirow[t]{2}{*}{ No } & \multirow[t]{2}{*}{ Pernyataan } & \multicolumn{5}{|c|}{ Proporsi Jawaban Responden } & \multirow[t]{2}{*}{$\begin{array}{l}\text { Rata- } \\
\text { Rata }\end{array}$} & \multirow[t]{2}{*}{ Kriteria } \\
\hline & & STS & $\mathrm{TS}$ & $\mathrm{N}$ & $\mathrm{S}$ & SS & & \\
\hline 1 & $\begin{array}{l}\text { Gaji yang diberikan oleh } \\
\text { perusahaan dapat memnuhi } \\
\text { kebutuhan hidup saya. }\end{array}$ & 1 & 3 & 7 & 27 & 9 & 3,85 & Tinggi \\
\hline 2 & $\begin{array}{l}\text { Insentif yang diberikan oleh } \\
\text { perusahaan memberikan } \\
\text { semangat saya dalam bekerja }\end{array}$ & 4 & 7 & 15 & 12 & 9 & 3,32 & Cukup \\
\hline 3 & $\begin{array}{l}\text { Bonus yang diberikan oleh } \\
\text { perusahaanmeningkatkan } \\
\text { semangat kerja saya. }\end{array}$ & 3 & 14 & 7 & 17 & 6 & 3,19 & Cukup \\
\hline 4 & $\begin{array}{l}\text { Asuransi kesehatan yang } \\
\text { diberikan oleh perusahaan } \\
\text { memberikan rasa aman bagi } \\
\text { saya. }\end{array}$ & 3 & 10 & 14 & 10 & 10 & 3,30 & Cukup \\
\hline 5 & $\begin{array}{l}\text { Tunjangan yang diberikan oleh } \\
\text { perusahaan sesuai dengan } \\
\text { harapan saya. }\end{array}$ & 1 & 3 & 6 & 23 & 14 & 3,98 & Tinggi \\
\hline \multicolumn{7}{|c|}{ Rata-rata } & 3,53 & Tinggi \\
\hline
\end{tabular}

Sumber : Data diolah, 2018.

Tabel 8 menunjukan rata-rata dari 5 pernyataan responden mengenai kompensasi yaitu sebesar 3,53 yang berarti bahwa kompensasi dalam kriteria tinggi. Indikator yang mempunyai rata-rata skor tertinggi ditunjukan pada pernyataan "Tunjangan yang diberikan oleh perusahaan sesuai dengan harapan saya" dengan nilai rata-rata sebesar 3,98. Pernyataan tersebut disetujui oleh 23 karyawan yang berarti sebagian besar karyawan mendapatkan tunjangan yang sesuai dengan harapan. Indikator yang memiliki rata-rata skor paling rendah adalah pernyataan “ Bonus yang diberikan oleh perusahaan meningkatkan semangat kerja saya" dengan nilai skor rata-rata 3,19. Pernyataan tersebut tidak disetujui oleh 14 orang karyawan, ini berarti sebagian karyawan merasa bonus yang diberikan perusahaan masih kurang sehingga mereka tidak terlalu bersemangat dalam bekerja. 
Ida Bagus Gede Wirabawa Dhananjaya, Pengaruh Kompensasi Finansial, Budaya...

\section{Penilaian Responden Tentang Budaya Organisasi}

Penilaian responden tentang budaya organisasi diukur dengan 6 butir pernyataan. Data tentang pernyataan tersebut dapat dilihat pada Tabel 9.

Tabel 9.

Jawaban Responden Tentang Budaya Organisasi

\begin{tabular}{|c|c|c|c|c|c|c|c|c|}
\hline \multirow[t]{2}{*}{ No } & \multirow[t]{2}{*}{ Pernyataan } & \multicolumn{5}{|c|}{ Proporsi Jawaban Responden } & \multirow[t]{2}{*}{$\begin{array}{l}\text { Rata- } \\
\text { Rata }\end{array}$} & \multirow[t]{2}{*}{ Kriteria } \\
\hline & & STS & TS & $\mathrm{N}$ & $\mathrm{S}$ & SS & & \\
\hline 1 & $\begin{array}{l}\text { Saya merasa bangga terhadap } \\
\text { perusahaan saya. }\end{array}$ & 3 & 9 & 12 & 9 & 14 & 3,47 & Kuat \\
\hline 2 & $\begin{array}{l}\text { Saya merasa dihargai oleh } \\
\text { perusahaan saya. }\end{array}$ & 5 & 8 & 13 & 17 & 4 & 3,15 & Sedang \\
\hline 3 & $\begin{array}{l}\text { Saya bersikap optimis dalam } \\
\text { bekerja. }\end{array}$ & 4 & 10 & 8 & 14 & 11 & 3.38 & Sedang \\
\hline 4 & $\begin{array}{l}\text { Saya mengetahui tujuan } \\
\text { perusahaan saya. }\end{array}$ & 2 & 7 & 15 & 15 & 8 & 3.43 & Kuat \\
\hline 5 & $\begin{array}{l}\text { Saya mengetahui pentingnya } \\
\text { pekerjaan saya }\end{array}$ & 4 & 10 & 10 & 9 & 14 & 3,40 & Sedang \\
\hline 6 & $\begin{array}{l}\text { Saya hanya peduli pada urusan } \\
\text { pekerjaan saya sendiri }\end{array}$ & 2 & 10 & 18 & 11 & 6 & 3.19 & Sedang \\
\hline \multicolumn{7}{|c|}{ Rata-rata } & 3,34 & Sedang \\
\hline
\end{tabular}

Sumber : Data diolah, 2018

Tabel 9 menunjukan rata-rata skor dari 6 pernyataan responden mengenai budaya organisasi sebesar 3,34 yang berarti budaya organisasi yang dirasakan karyawan Koperasi Asadana Semesta Denpasar tergolong dalam kriteria sedang. Indikator yang memiliki nilai rata-rata skor tertinggi adalah pernyataan "Saya merasa bangga terhadap perusahaan saya" dengan rata-rata skor sebesar 3,47. Pernyataan tersebut menjelaskan bahwa 14 orang karyawan merasa bangga dengan perusahaannya. Sedangkan indikator dengan nilai rata-rata terendah ditunjukan pada pernyataan "saya merasa dihargai oleh perusahaan saya" dengan nilai rata-rata skor sebesar 3,15. Pernyataan tersebut tidak disetujui oleh 8 orang yang berarti karyawan bangga terhadap perusahaan mereka namun beberapa karyawan merasa tidak dihargai oleh perusahaannya. 


\section{Penilaian Responden Tentang Kepemimpinan}

Penilaian responden tentang kepemimpinan diukur dengan 6 butir pernyataan. Data tentang pernyataan tersebut dapat dilihat pada Tabel 10.

Tabel 10.

Jawaban Responden Tentang Kepemimpinan

\begin{tabular}{|c|c|c|c|c|c|c|c|c|}
\hline \multirow{2}{*}{ No } & \multirow{2}{*}{ Pernyataan } & \multicolumn{5}{|c|}{ Proporsi Jawaban Responden } & \multirow{2}{*}{$\begin{array}{l}\text { Rata- } \\
\text { Rata }\end{array}$} & \multirow{2}{*}{ Kriteria } \\
\hline & & STS & TS & $\mathrm{N}$ & $\mathrm{S}$ & SS & & \\
\hline 1 & $\begin{array}{l}\text { Pimpinan saya pandai membaca } \\
\text { situasi. }\end{array}$ & 1 & 10 & 9 & 20 & 7 & 3,47 & Baik \\
\hline 2 & $\begin{array}{l}\text { Pimpinan saya peka terhadap } \\
\text { masukan. }\end{array}$ & 4 & 10 & 8 & 13 & 12 & 3,40 & Cukup \\
\hline 3 & $\begin{array}{l}\text { Pimpinan saya dapat } \\
\text { menciptakan susana lingkungan } \\
\text { yang baik. }\end{array}$ & 3 & 10 & 12 & 12 & 10 & 3,34 & Cukup \\
\hline 4 & $\begin{array}{l}\text { Pimpinan saya bersedia } \\
\text { melimpahkan sebagian } \\
\text { wewenang kepada karyawan. }\end{array}$ & 3 & 12 & 11 & 13 & 8 & 3,23 & Cukup \\
\hline 5 & $\begin{array}{l}\text { Pimpinan saya memberikan } \\
\text { tugas dengan lebih bersifat } \\
\text { permintaan daripada instruktif. }\end{array}$ & 5 & 9 & 14 & 11 & 8 & 3,17 & Cukup \\
\hline 6 & $\begin{array}{l}\text { Pimpinan saya cenderung } \\
\text { menciptakan suasana saling } \\
\text { percaya terhadap karyawan. }\end{array}$ & 5 & 14 & 4 & 16 & 8 & 3,17 & Cukup \\
\hline \multicolumn{7}{|c|}{ Rata-rata } & 3,30 & Cukup \\
\hline
\end{tabular}

Sumber : Data diolah, 2018

Tabel 10 menunjukan rata-rata skor dari 6 pernyataan responden mengenai kepemimpinan sebesar 3,30 yang berarti kepemimpinan yang dirasakan karyawan Koperasi Asadana Semesta Denpasar tergolong dalam kriteria cukup. Indikator yang memiliki nilai rata-rata skor tertinggi adalah pernyataan "Pimpinan saya pandai membaca situasi" dengan rata-rata skor sebesar 3,47. Dapat disimpulkan bahwa sebagian besar karyawan merasa pemimpin mereka sangat pandai dalam membaca situasi. Sedangkan indikator dengan nilai rata-rata terendah ditunjukan pada pernyataan "Pimpinan saya memberikan tugas dengan lebih bersifat permintaan daripada instruktif dan pimpinan saya cenderung menciptakan suasana 
Ida Bagus Gede Wirabawa Dhananjaya, Pengaruh Kompensasi Finansial, Budaya...

saling percaya terhadap karyawan" dengan nilai rata-rata skor sebesar 3,17. Dua pernyataan tersebut tidak disetujui masing-masing 9 dan 14 karyawan, ini berarti bahwa 23 karyawan merasa pimpinan selalu menggunakan bahasa instruktif daripada permintaan dan karyawan merasa tidak mendapat kepercayaan dari pemimpin mereka.

\section{Hasil Analisis Regresi Linier Berganda}

Model Regresi Linier Berganda digunakan untuk mengetahui pengaruh kompensasi finansial, budaya organisasi, dan kepemimpinan terhadap turnover intention. Hasil analisis dapat dilihat pada Tabel 11.

Tabel 11.

Hasil Analisis Regresi Linier Berganda

\begin{tabular}{lcccc}
\hline \multicolumn{1}{c}{ Variabel } & Standardized Beta & Std. Error & t hitung & Sig. uji t \\
\hline (Constanta) & 6,559 & 0,282 & 23,284 & 0,000 \\
Kompensasi Finansial & $-0,326$ & 0,150 & $-2,167$ & 0,036 \\
Budaya Organisasi & $-0,182$ & 0,081 & $-2,245$ & 0,030 \\
Kepemimpinan & $-0,622$ & 0,114 & $-5,439$ & 0,000 \\
\hline$R$ Square & 0,876 & & \\
Adjusted $R$ Square & 0,867 & & \\
F Statistik & 101,039 & & \\
Signifikansi Uji F & 0,000 & & & \\
\hline
\end{tabular}

Sumber : Data diolah, 2018

Berdasarkan hasil analisis regresi linier berganda seperti yang disajikan pada tabel 11 maka persamaan regresinya adalah sebagai berikut :

$\mathrm{Y}=6,559-0,326 \mathrm{X} 1-0,182 \mathrm{X} 2-0,622 \mathrm{X} 3$

Koefisien determinasi sebesar 0,876 mempunyai arti bahwa sebesar 87,6\% variasi turnover intention dipengaruhi oleh variasi kompensasi finansial, budaya organisasi, dan kepemimpinan, sedangkan sisanya sebesar 12,4\% djelaskan oleh faktor lain yang tidak dimasukkan ke dalam model. 


\section{Hasil Uji Normalitas}

Uji Normalitas bertujuan untuk mengetahui residual dari model regresi dibuat berdistribusi normal atau tidak. Hasil Uji Normalitas dapat dilihat pada Tabel 12.

Tabel 12.

Hasil Uji Normalitas

\begin{tabular}{cc}
\hline \multicolumn{3}{c}{ Unstandardized Residual } \\
\hline N & 47 \\
Kolmogorov-Smirnov Z & 0,744 \\
Asymp.Sig.(2-tailed) & 0,638 \\
\hline Sumber: Data diolah, 2018 &
\end{tabular}

Berdasarkan Tabel 12 dapat dilihat bahwa nilai Kolmogorov Sminarnovsebesar 0,744, sedangkan nilai Asymp.Sig. (2-tailed) sebesar 0,638. Hasil tersebut mengindikasikan bahwa model persamaan regresi tersebut berdistribusi normal karena nilai Asymp. Sig. (2-tailed) 0,638lebih besar dari nilai alpha 0,05 .

\section{Hasil Uji Multikoleniaritas}

Uji Multikoleniaritas bertujuan untuk menguji apakah pada model regresi ditemukan adanya korelasi antar variabel bebas. Hasil Uji Multikoleniaritas dapat dilihat pada Tabel 13 .

Tabel 13.

\section{Hasil Uji Multikoleniaritas}

\begin{tabular}{ccc}
\hline Variabel & Tolerance & VIF \\
\hline KompensasiFinansial $\left(\mathrm{X}_{1}\right)$ & 0,238 & 4,207 \\
Budaya Organisasi $\left(\mathrm{X}_{2}\right)$ & 0,529 & 1,890 \\
Kepemimpinan $\left(\mathrm{X}_{3}\right)$ & 0,238 & 4,202 \\
\hline Sumber: Data diolah, 2018 & &
\end{tabular}

Berdasarkan Tabel 13 dapat dilihat bahwa nilai tolerance dan VIF dari seluruh variable menunjukkan bahwa nilai tolerance untuk setiap variabel lebih 
Ida Bagus Gede Wirabawa Dhananjaya, Pengaruh Kompensasi Finansial, Budaya...

besar dari $10 \%$ dan nilai VIF lebih kecil dari 10 yang berarti model persamaan regresibebas dari multikolinearitas.

\section{Hasil Uji Heterokedastisitas}

Uji Heterokedastisitas bertujuan untuk mengetahui apakah dalam model regresi terjadi ketidaksamaan varian dari residual satu pengamatan ke pengamatan lain. Hasil Uji Heterokedastisitas dapat dilihat pada Tabel 14.

Tabel 14.

Hasil Uji Heteroskedastisitas

\begin{tabular}{|c|c|c|c|c|c|c|}
\hline \multirow{2}{*}{ No } & \multirow{2}{*}{ Model } & \multicolumn{2}{|c|}{$\begin{array}{c}\text { Unstandardized } \\
\text { Coefficients }\end{array}$} & \multirow{2}{*}{$\begin{array}{c}\begin{array}{c}\text { Standardized } \\
\text { Coefficients }\end{array} \\
\text { Beta }\end{array}$} & \multirow{2}{*}{$\mathrm{t}$} & \multirow{2}{*}{ Sig. } \\
\hline & & B & $\begin{array}{l}\text { Std. } \\
\text { Error }\end{array}$ & & & \\
\hline 1 & Constant & 0,303 & 0,192 & & 1,580 & 0,121 \\
\hline 2 & $\begin{array}{l}\text { Kompensasi } \\
\text { Finansial }\end{array}$ & $-0,084$ & 0,102 & $-0,254$ & $-0,821$ & 0,416 \\
\hline 3 & Buadaya Organisasi & 0,007 & 0,055 & 0,026 & 0,124 & 0,902 \\
\hline 4 & Kepemimpinan & 0,074 & 0,078 & 0,294 & 0,951 & 0,347 \\
\hline
\end{tabular}

Pada Tabel 14 dapat dilihat bahwa nilai signifikansi dari variabel kompensasi, budaya organisasi, dan kepemimpinan masing-masing sebesar 0,416 , 0,902 dan 0,347 . Nilai tersebut lebih besar dari 0,05 yang berarti tidak terdapat pengaruh antara variabel bebas terhadap absolute residual. Dengan demikian, model yang dibuat tidak mengandung gejala heteroskedastisitas.

Signifikansi Tabel Anova menunjukkan besarnya angka probabilitas atau signifikansi pada perhitungan Anova. Nilai yang tertera digunakan untuk uji kelayanan Model Analisis (dimana sejumlah variabel x mempengaruhi variabel y) dengan ketentuan angka probabilitas yang baik untuk digunakan sebagai model regresi harus $<0,05$. Nilai ini bisa dilihat pada kolom Sig. Jika Sig. $<0,05$, maka 
Model Analisis dianggap layak. Jika Sig. > 0,05, maka Model Analisis dianggap tidak layak.

\section{Uji Kelayakan Model (Uji F)}

Uji F dilakukan untuk mengetahui pengaruh variabel bebas secara bersamasama mempunyai pengaruh yang nyata atau signifikan terhadap variabel terikat. Hasil Uji F dapat dilihat pada Tabel 15.

Tabel 15.

Uji Anova

\begin{tabular}{lrrrrr}
\hline \multicolumn{1}{c}{ Model } & Sum of Squares & df & Mean Square & F & \multicolumn{1}{c}{ Sig. } \\
\hline Regression & 46.993 & 3 & 15.664 & 101.039 & $.000^{\mathrm{a}}$ \\
Residual & 6.666 & 43 & .155 & & \\
Total & 53.660 & 46 & & & \\
\hline
\end{tabular}

Sumber: Data diolah, 2018

Mengacu pada Tabel $15 \mathrm{~F}$ hitung $=101,039$. Nilai Fhitung > Ftabel, $101,039>2,82$, dengan nilai sig. 0,000 < 0,05. Kesimpulannya, pada kelompok yang diuji memiliki perbedaan yang nyata (signifikan) berarti bahwa kompensasi, budaya organisasi, dankepemimpinan,secara simultan berpengaruh signifikan terhadap Turnover Intention.

\section{Hasil Uji Hipotesis (Uji t)}

Uji t dilakukan untuk mengetahui seberapa besar pengaruh variabel bebas terhadap variabel terikat secara parsial. Uji t dilakukan dengan membandingkan nilai signifikan yang dihasilkan dengan alpha 0,05 . Hipotesis 1 yakni pengaruh kompensasi finansial terhadap turnover intention memiliki nilai signifikan sebesar $0,036<0,05$, dengan nilai beta $-0,326$. Maka dapat dikatakan bahwa kompensasi finansial berpengaruh negatif dan signifikan terhadap turnover intention. Hipotesis 2 yakni pengaruh budaya organisasi terhadap turnover intention 
Ida Bagus Gede Wirabawa Dhananjaya, Pengaruh Kompensasi Finansial, Budaya...

memiliki nilai signifikan sebesar $0,030<0,05$, dengan nilai beta $-0,182$. Maka dapat dikatakan bahwa budaya organisasi berpengaruh negatif dan signifikan terhadap turnover intention. Hipotesis 3 yakni pengaruh kepemimpinan terhadap turnover intention memiliki nilai signifikan sebesar $0,000<0,05$, dengan nilai beta -0,622. Maka dapat dikatakan bahwa kepemimpinan berpengaruh negatif dan signifikan terhadap turnover intention.

\section{Pengaruh Kompensasi Finansial Terhadap Turnover Intention}

Hipotesis satu $\left(\mathrm{H}_{1}\right)$ pada penelitian ini menyatakan bahwa kompensasi finansial berpengaruh negatif terhadap turnover intention karyawan Koperasi Asadana Semesta Denpasar. Hasil analisis uji hipotesis menunjukan bahwa kompensasi finansial berpengaruh negatif terhadap turnover intention, sehingga hipotesis satu diterima. Berarti terdapat indikasi bahwa semakin rendah kompensasi finansial yang diterima karyawan maka semakin tinggi turnover intention.

Hasil penelitian ini sesuai dengan penelitian yang dilakukan oleh Astiko (2012) yang menyatakan bahwa kompensasi berpengaruh negatif terhadap turnover intention. Pendapat tersebut didukung oleh pendapat Jandu (2015) yang menyatakan kompensasi berpengaruh negatif signifikan terhadap turnover intention. Sistem kompensasi finansial yang baik mampu meneken intensitas keinginan karyawan untuk keluar dari perusahaan. Sukron (2011) berpendapat bahwa adanya kompensasi finansial selain gaji pokok seperti insentif dan tunjangan mampu menekan intensitas keinginan keluarnya karyawan dari perusahaan. 


\section{Pengaruh Budaya Organisasi Terhadap Turnover Intention}

Hipotesis dua $\left(\mathrm{H}_{2}\right)$ dalam penelitian ini adalah budaya organisasi berpengaruh negatif terhadap turnover intention karyawan Koperasi Asadana Semesta Denpasar. Hasil analisis uji hipotesis menunjukan bahwa budaya organisasi berpengaruh negatif terhadap turnover intention, sehingga hipotesis dua diterima. Terdapat indikasi bahwa semakin kuat budaya organisasi maka semakin rendah turnover intention.

Penelitian Malik (2014) menyatakan bahwa budaya organisasi berpengaruh negatif terhadap turnover intention. Pendapat tersebut didukung Setyanto (2013) yang menyatakan bahwa budaya organisasi berpengaruh negatif terhadap turnover intention di perusahaan Teladan Prima Group. Budaya organisasi merupakan nilai budaya yang dianut untuk memperkuat ikatan antar individu untuk bekerjasama. Widayati dan Yunia (2016) berependapat apabila budaya organisasi kuat maka intensitas keinginan keluar karyawan akan menurun.

\section{Pengaruh Kepemimpinan Terhadap Turnover Intention}

Hipotesis tiga $\left(\mathrm{H}_{3}\right)$ dalam penelitian ini adalah kepemimpinan berpengaruh negatif terhadap turnover intention karyawan Koperasi Asadana Semesta Denpasar. Hasil analisis uji hipotesis menunjukan bahwa kepemimpinan berpengaruh negatif terhadap turnover intention, yang berarti hipotesis tiga diterima. Terdapat indikasi bahwa semakin baik kepemimpinan yang diterapkan maka semakin rendah turnover intention.

Kepemimpinan adalah suatu seni yang dimiliki seorang pemimpin untuk mempengaruhi individu untuk mencapai keinginan pemimpin. Krisyanto (2005) 
Ida Bagus Gede Wirabawa Dhananjaya, Pengaruh Kompensasi Finansial, Budaya...

menyatakan bahwa kepemimpinan berpengaruh negatif signifikan terhadap turnover intention. Pendapat tersebut didukung penelitian yang dilakukan Astiko (2012) yang menyatakan bahwa kepemimpinan berpengaruh negatif terhadap turnover intention melalui kepuasan kerja. Pimpinan yang mampu mengarahkan sesuai tata tertib dan tujuan yang jelas pada pada organisasi akan berdampak terhadap kepuasan karyawan sehingga menurunkan niat karyawan untuk keluar dari organisasi. Sukron (2011) menyatakan bahwa pemimpin menginspirasi bawahan dengan memberikan solusi yang tepat dalam pemecahan masalah dan mampu memberikan rasa nyaman pada karyawan sehingga mampu menekan keinginan karyawan untuk keluar dari organisasi.

\section{Implikai Hasil Penelitian}

Implikasi hasil penelitian ini diharapkan mampu memberikan informasi penting tentang apa saja yang perlu diperhatikan oleh setiap perusahaan demi berkembangnya SDM di setiap perusahaan yang menyangkut variabel variabel penelitian ini. Kompensasi finansial merupakan hak yang diterima oleh karyawan sebagai balas jasa yang dilakukan karyawan. Hasil penelitian menunjukan bahwa kompensasi finansial berpengaruh negatif terhadap turnover intention. Hal ini mengandung implikasi agar kedepannya perusahaan memperhatikan sistem pemberian kompensasi finansial dengan baik sehingga mampu meningkatkan semangat kerja karyawan dan menekan turnover intention.

Sedangkan budaya organisasi merupakan sistem nilai - nilai, keyakinan dan tradisi bersama yang menghasilkan norma prilaku yang menjadi satu kesatuan. Hasil penelitian menunjukan bahwa budaya organisasi berpengaruh negatif 
terhadap turnover intention. Hal tersebut mengandung implikasi bahwa kedepannya perusahaan diharapkan menanamkan nilai - nilai, keyakinan dan tradisi bersama yang menunjukan prilaku positif sehingga dapat mempersatukan seluruh karyawan untuk mencapai tujuan bersama. Berikutnya adalah kepemimpinan yang merupakan suatu kemampuan, ilmu atau seni dari individu yang disebut pemimpin untuk menyatukan dan mengarahkan individu lainnya mencapai tujuan bersama dan mampu menekan turnover intention.

\section{Keterbatasan Penelitian}

Penelitian ini telah dilaksanakan sesuai dengan prosedur ilmiah, namun masih memiliki keterbatasan seperti faktor yang mempengaruhi turnover intention dalam penelitian ini hanya terdiri dari tiga variabel, yaitu kompensasi finansial, budaya organisasi dan kepemimpinan, sedangkan masih banyak faktor lain yang mungkin mempengaruhi turnover intention. keterbatasan berikutnya adalah adanya keterbatasan penelitian dalam menggunakan kuesioner dengan butir butir pernyataan, terkadang pernyataan yang diberikan responden tidak sepenuhnya menunjukan keadaan yang sesungguhnya.

\section{SIMPULAN DAN SARAN}

Berdasarkan hasil analisis penelitian dan hasil pembahasan pada babsebelumnya maka simpulan dari penelitian ini adalah 1)Kompensasi finansial berpengaruh negatif terhadap Turnover Intention di Koperasi Asadana Semesta Denpasar. Hal ini menunjukan bahwa semakin tinggi kompensasi yang diterima karyawan, maka semakin rendah turnover intention karyawan di Koperasi Asadana Semesta Denpasar. 2) Budaya Organisasi berpengaruh negatif terhadap 
Ida Bagus Gede Wirabawa Dhananjaya, Pengaruh Kompensasi Finansial, Budaya...

Turnover Intention di Koperasi Asadana Semesta Denpasar. Hal ini menunjukkan bahwa semakin kuat budaya organisasi maka semakin rendah turnover intention karyawan di Koperasi Asadana Semesta Denpasar. 3) Kepemimpinan berpengaruh negatif terhadap Turnover Intention di Koperasi Asadana Semesta Denpasar. Hal ini menunjukan bahwa semakin baik kepemimpinan yang diterapkan, maka semakin rendah turnover intention karyawan di Koperasi Asadana Semesta Denpasar.

Berdasarkan hasil analisis penelitian, pembahasan dan kesimpulan terdapat beberapa saran yang dapat dipergunakan sebagai bahan pertimbangan adalah 1) Ditemukan skor tertinggi pada pernyataan ketiga yaitu karyawan sesegera mungkin akan meninggalkan perusahaan. Oleh sebab itu perusahaan diharapkan dapat memperhatikan pemberian kompensasi, penerapan budaya organisasi dan kemampuan pemimpin sehingga karyawan memiliki semangat dan tetap bertahan dalam organisasi. 2) Berdasarkan hasil analisis variabel kompensasi finansial skor terendah diperoleh pada pernyataan bonus yang diberikan perusahaan meningkatkan semangat kerja. Perusahaan diharapkan memperhatikan penerapan pemberian bonus kepada karyawan yang berprestasi sehingga karyawan memiliki semangat memberikan kemampuan terbaik untuk perusahaan. 3) Berdasarkan hasil analisis variabel budaya organisasi ditemukan skor terendah pada pernyataan kedua yaitu karyawan merasa dihargai oleh perusahaan. diharapkan perusahaan memperhatikan setiap kemampuan yang diberikan oleh karyawan, hendaknya kemampuan karyawan dihargai dengan cara pemberian pengahargaan atau ucapan terimakasih pada karyawan yang sudah lama bekerja di perusahaan. 4) 
Berdasarkan hasil analisis variabel kepemimpinan ditemukan skor terendah pada pernyataan pimpinan memberikan tugas dengan bersifat permintaan dan menciptakan suasana saling percaya terhadap karyawan. diharapkan perusahaan mengembangkan kemampuan pemimpin berkomunikasi seperti lebih memilih pemberian tugas bersifat permintaan, memberikan kepercayaan pada karyawan agar karyawan mampu berkembang dan antusias bekerjasama dengan pemimpinnya.

\section{DAFTAR RUJUKAN}

Baek-Kyoo, Sunyoung, P. (2009). Career Satisfaction, Organizational Comitment, and Turnover Intention: The Effect of Goal Orientation, Organizational Learning Culture and Developmental Feedback. Leadership and Organization Development Journal. 31(6), pp: 482-500.

Choi, S.L., Lee, Y.T. (2011). Relationship Between Leadership Style, Job Satisfaction and Employee's Turnover Intention: A Literature Review. Research Journal of Business Management. 5(1), pp: 91-100.

Cinar, O., Fatih K., and Imran A. (2014). The Relationship among Organizational Cynicism, Job Insecurity and Turnover Intention: A Survey Study in Erzurum/Turkey. International Strategic Management Conference. 150, pp: $429-437$.

Devi, N.L.M.S., dan Sudibia, G.A. (2015). Analisis Pengaruh Job Insecurity dan Kompensasi Finansial Terhadap Kepuasan Kerja dan Turnover Intention: (Studi Pada Karyawan Kontrak Di Bali Dinasty Resort). EJurnal Manajemen Unud. 4(4): 1047-1066.

Fah, B.C.Y., Yeoh S.F., Lim C.L., and Syuhaily O. (2010) .An Exploratory Study on Turnover Intention among Private Sector Employees. International Journal of Business and Management. 5(8), pp: 57-64.

Flynn, F.J., Chatman, J.A. (2001). Strong Cultures and Innovation: Oxymoron or Opportunity? In C.L. Cooper, S. Cartwright and P.C. Earley. International Handbook of Organizational Culture and Climate. New York: John Wiley and Sons.

Green, A.E., Elizabeth A.M., and Gregory A.A. (2013). Transformational Leadership Moderators the Relationship between Emotional Exhaustion and Turnover Intention among Community Mental Health Providers.Comonity Mental Health Journal. 49(4), pp: 373-379. 
Ida Bagus Gede Wirabawa Dhananjaya, Pengaruh Kompensasi Finansial, Budaya...

Harnoto. (2002). Manajemen Sumber Daya Manusia. Jakarta: Prehallindo.

Hasibuan, Malayu S.P. (2013). Manajemen Sumber Daya Manusia. Jakarta: Bumi Aksara.

Krisyanto, E. (2005).Pengaruh Gaya Kepemimpinan dan Kepuasan Kerja terhadap Turnover Intention Karyawan PT. Garuda Karya Mandiri. Jurnal Ilmiah Ilmu Manajemen. pp: 59-68.

Lewis, D. (2002). Five Years on the Organizational Culture Saga Revisited. Leadership and Organizational Development Journal. 23(1), pp: 280287.

Mahdi, F., Mohamad Z.M.Z., Mohd, R.M.N., Ahmad, A.S dan Abang, S.A.N. (2012). The Relationship Between Job Satisfaction and Turnover Intention. American Journal of Applied Science. 9(9), pp: 1518-1526.

Malik, A. (2014). Pengaruh Budaya Organisasi dan Loyalitas Kerja dengan Intensi Turnover pada Karyawan PT. Cipaganti Heavy Equipment Samarinda. Ejournal Psikologi.2(1), pp: 65-72.

Mangkunegara, A.P. (2009). Manajemen Sumber Daya Manusia Perusahaan. Bandung: PT. Remaja Rusdakarya.

Milkovich, G.T., Newman, J.M., Milkovich, C. (2002). Compensation. New York : McGraw-Hill.

Negara, K.A.S. (2017). Pengaruh Ketidakamanan Kerja dan Stres Kerja terhadap Turnover Intention pada Sense Sunset Hotel Seminyak. E-Jurnal Manajemen Unud. 6(7), pp: 3934-3961.

Orwa, H. (2012). Labour Turnover In The Sugar Industry In Kenya. European Journal of Business and Management. 4(9), pp: 111-119.

Panggabean, S.M. (2004). Manajemen Sumber Daya Manusia. Bogor: Ghalia Indonesia.

Putrianti, A.D. (2014). Pengaruh Kompensasi dan Motivasi Kerja Terhadap Turnover Intention. Jurnal Administrasi Bisnis. 12(2), pp:1-9.

Robbins, S.P.(2001). Organizational Behavior. New Jersey: Pearson Education International.

Robbins, S.P. (2006). Perilaku Organisasi. Klaten: PT Intan Sejati.

Saeka, I.P.A.P., Suana, I.W. (2016). Pengaruh Kepuasan Kerja, Komitmen Organisasional dan Stres Kerja terhadap Turnover IntentionKaryawan PT. Indonusa Algemas Prima Bali. E-Jurnal Manajemen Unud. 5(6), pp: 3736-3760. 
Setyanto, A., Suharnomo, Sugiono. (2013). Analisis Pengaruh Kepuasan Kerja dan Iklim Organisasi Terhadap Keinginan Keluar (intention to quit) dengan Komitmen Organisasional Sebagai Variabel Intervening (Pada Perusahaan Perkebunan Kelapa Sawit Teladan Prima Group). Ejournal undip. 10(1), pp: 75-81.

Shim, M. (2010). Factors Influencing Child Welfare Employee's Turnover: Focusing on Organizational Culture and Climate. Children and Youth Services Review. 32(1), pp: 847-856.

Shun, K. (2011). The Turnover Intentions For Contruction Engineers. Journal of Marine Science and Technology. 19(5), pp: 550-556.

Siagian, S.P. (2010). Manajemen Sumber Daya Manusia. Jakarta: Bumi Aksara.

Simamora, H. (2006). Manajemen Sumber Daya Manusia. Yogyakarta: STIE YKPN.

Stoner, James, A.F., Freeman, E., Daniel, R., Gilbert, D.R. (1996). Manajemen, Alih Bahasa Alexander Sindono. Jakarta: PT. Prehallindo.

Sugiyono. (2012). Metode Penelitian Bisnis. Bandung : Alfabeta

Utama, M.S. (2011). Buku Ajar Aplikasi Analisis Kuantitatif. Denpasar: Sastra Utama.

Wang, Y.L., Hsieh, L. (2010). Chinese Employees' Work Values and Turnover Intentions in Multinational Companies The Mediating Effect Of Pay Satisfaction. Social Behavior And Personality. 38(7), pp: 871-894.

Widayati, C., Yunia, Y. (2016). Pengaruh Kompensasi dan Budaya Organisasi terhadap Turnover Intention. Jurnal Manajemen. 20(3), pp: 387-401.

Widodo, S.E. (2015). Manajemen Pengembangan Sumber Daya Manusia. Yogyakarta: Pustaka Pelajar.

Winoto, Paulus. (2015). Pengaruh Kompensasi dan Kepuasan Kerja terhadap Turnover Intention Karyawan (Studi Kasus pada PT Multi Abadi Sejahtera). Jurnal Ilmiah Manajemen Bisnis. 15(2), pp: 81-97.

Wirawan, N. (2014). Statistik. Denpasar: Keraras Emas. 